УДК 811.16:929 Хавранек Б.

$811.163 .4 / .6-26$

https://doi.org/10.18485/msc50.2021.2.ch28

Алојз Једличка

\title{
БОХУСЛАВ ХАВРАНЕК О КНИЖЕВНИМ ЈЕЗИЦИМА ЈУГОСЛОВЕНСКИХ НАРОДА
}

Факта развоја књижевних језика на територији Југославије била су за Б. Хавранека жива истраживачка реалност на којој је у својим славистичким компаративистичким студијама и у својим специјалним радовима посвећеним општој проблематици књижевног језика и словенских књижевних језика, посебно на њиховом развоју, систематски и стално радио и чијем је дубљем осветљавању доприносио. Познавање основних факата стицао је постепено непрестаним праћењем лингвистичке литературе а реализовао га и продубљивао непосредним личним и радним контактима са старијим југословенским лингвистима, нарочито с Александром Белићем, Стјепаном Ившићем, Франом Рамовшем, Рајком Нахтигалом, Миливојем Павловићем и др., а касније и с многим млађим лингвистима, посебно са специјалистима у области проучавања књижевних језика. Југословенска језичка реалност га је привлачила сложеношћу језичке ситуације и њеном историјском променљивошћу, специфичношћу која је подстицала на конфронтацију и илустративношћу типолошких црта погодних за конкретизацију опште проблематике књижевног језика. Тако су у радовима Б. Хавранека заступљена факта развоја српскохрватског књижевног језика (укључујући и диферентну ситуацију српску и хрватску), факта из литературе хрватскоглагољске и из словеначког књижевног језика, односно факта која се тичу узајамних односа тих језика. У обради тих факата и при њиховој интерпретацији огледа се савремено стање лингвистичке методологије, савремени научни контекст и актуалност одређених научних задатака и приступања њиховом решавању.

1. У првом периоду тридесетих година Б. Хавранек опсежно и детаљно користи језички материјал из књижевних језика народа Југославије у својим упоредноисторијским радовима. Ту мислим на студију Př́spěvek $k$ tvoření slov ve spisovných jazycích slovanských (Прилог грађењу речи у сло- 
венским књижевним језицима - Slavia 7, 1928/29, с. 766, објав. и у Studie o spisovném jazyce, Praha 1963, с. 265), посвећеној придевима са значењем латинских адјектива на -bilis, затим нарочито методолошки значајну студију $K$ adaptaci fonologických systémů ve spisovných jazycích slovanských (О адаптацији фонолошких система у словенским књижевним језицима - зб. Studie..., 1963, с. 282, првобитно на немачком Zur adaptation der phonologischen Systeme in den Schriftsprachen, Travaux du Cercle Linguistique de Prague 4, 1931, s. 267). Већ ту - нарочито у другој студији - истиче специфичне црте књижевног језика, које проистичу из његове специјалне функције и на конкретним фактима илуструје тезу да се фонолошки систем књижевног језика прилагођује специјалном циљу, да се целисходно мења, често и поново ствара. Избор одговарајућег система с обзиром на специјалне функције књижевног језика важан је приликом конституисања књижевних језика. У томе између појединих словенских књижевних језика постоје разлике. Б. Хавранек изразиту разлику види између старијих и млађих словенских књижевних језика који су настали у 19. веку. При томе с тог гледишта карактерише и Вуков књижевни језик.

2. С краја тридесетих година две Хавранекове студије су директно посвећене књижевним језицима народа Југославије и то с гледишта њихова односа. И у ранијем периоду свога развоја упоредно проучавање развоја словенских књижевних језика концентрисало се на утврђивање узајамних односа између њих и њихова узајамног утицаја све док није било замењено истраживањима у правом конфронтационом смислу. Обе студије су унесене у зборник Co daly naše země Evropě a lidstvu (Шта су дале наше земље Европи и човечанству - I, 1939, II, 1940): Staročeská literatura $v$ hlaholském písemnictví charvátském (Старочешка књижевност у хрватској глагољској књижевности, I, с. 52) и Vliv nové spisovné češtiny na spisovné jazyky jihoslovenské (Утицај новог чешког књижевног језика на јужнословенске књижевне језике, II, с. 86). У првој, користећи се радом С. Ившића (Slavia 1, 1922/23 и 6, 1926), Хавранек анализира утицај чешког језика на језик хрватске глагољске литературе у периоду њеног врхунског процвата за Карла IV и на почетку хуситског периода; прати га у основним цртама на преводима значајних дела старе чешке књижевности, концентришући се при том на илустрацију тезе да уколико језик на који се преводи нема довољно средстава, нарочито лексичких, преузима их из језика оригинала, или их гради под његовим утицајем. Овој тематици се поново вратио недавно у зборнику $Z$ tradice slovenske kultury $v$ Čechách (Из традиције словенске културе у Чешкој - Univ. Karlova 1975) у чл. Vztahy klášiera na Slovanech k jazyku a literatuře charvátskohlaholské (Односи манастира Словена према хрватскоглагољском језику и књижевно- 
сти). При том је имао могућност да се ослони на новију богату литературу посвећену овој тематици и на нова сазнања стечена при проучавању лексичког фонда старог чешког језика у вези с радом на старочешком речнику. На основу тога показао је да у чешким споменицима, насталим у средини Емауског манастира и писаних глагољским писмом, постоје само незнатни трагови хрватскоглагољског језика, док у старој хрватскоглагољској литератури (од поч. 15. в.), у преводима са чешког (Pasionál, Lucidár, Ráj duše, kázání Husova), има доста лексичких бохемизама - они, међутим, нису прешли оквире хрватске глагољске литературе (изузев адјектива са суфиксом -тельан, ч. -telný). Реч је о верским, правним и општекултурним, искључиво апстрактним називима. При том Б. Хавранек инспиративно указује да су те речи из тих области које значе нове појмове у вези с новом друштвеном ситуацијом постепено преузимане и у књижевни језик пољски и украјински. Међутим, за разлику од С. Ившића, долази до закључка да су хрватски монаси, који су деловали у Емауском манастиру били и учитељи а не само ђаци; допринели су увођењу чешког језика као богослужбеног, а затим и на територији Хрватске као заштитници појачали улогу хрватскоглагољског језика као богослужбеног.

Богато документован је чланак о утицају чешког књижевног језика на југословенске књижевне језике. Овај се утицај, пре свега, показао у области лексике, дакле, у оном делу језичког система који је у другој фази чешког народног препорода био, захваљујући делатности водећег чешког будитеља и лексикографа Ј. Јунгмана, уз учешће његових савременика и сарадника, програмски допуњаван. Циљ је био да се чешки књижевни језик оспособи у потпуности да послужи потребама двеју функционалностилских сфера истакнутих тада у први план: сфери научној и уметничкој.

Продор чешких лексичких елемената у словеначки књижевни језик, пре свега, разуме се, у граматике и речнике има већ, свакако, дужу традицију. И тога се Хавранек дотакао и то у чланку Mluvnictví české 17. stoleti (Чешки граматички систем 17. в. - у зб. Co daly naše země Evropě a lidstvu I, c. 195, а прештампано је и у зб. Studie o spisovném jazyce, 1963, овде под измењеним називом Význam staršího českého mluvnictví pro jiné slovanské jazyky, c. 318). Ту помиње утицај граматике Вацлава Росе (Gramatica linguae bohemicae, 1672) на граматику Словенца Марка Похлина (Крањска граматика, 1768). Похлин преузима основне Росине погледе на језик а узима понешто и из његове граматике, нарочито из дела о творби речи; преузима и неке Росине неологизме - Роса је био управо познат и по својим неологизмима који су често, дакако, били сами 
себи циљ, а који су произилазили из претераног пуризма оног времена. Много чешких речи је доспело у касније словеначке граматике и речнике из радова Добровског и то у Дањкову и Метелкину граматику и у Мурков немачко-словеначки речник из 1833. г.; међутим, непосредне трагове у словеначком речнику оставили су идејни контакти чешке културе са словеначком средином четрдесетих и педесетих година.

Функционисање више словенских књижевних језика у једној држави - Аустријској монархији - отварало је услове за контакте и узајамно деловање у области лексичког фонда. Након 1848. то се нарочито дешавало у области стручне терминологије - ту су велики утицај имала два специјална терминолошка речника настала у редакцији Павла Јозефа Шафарика, Juridisch-politisch Terminologie für die slavischen Sprachen Österreichs (чешко издање 1850, хрватско, српско и словеначко - 1853). и Německo-česky slovník vědeckého názvosloví progymnásia a reálné školy (1853). Оба ова речника су резултат колективне сарадње, први пак и у међународним оквирима. У комисији за правну и политичку терминологију радили су тада истакнути слависти, од чешких и словачких, поред Шафарика, К. J. Ербен, Ј. Колар, А. Шембера, од словеначких Фр. Миклошич, од стране југословенске - В. Караџић и Мажуранић. При том је изражена и потреба за зближавањем словенске терминологије, а дат је и нацрт критеријума за њену реализацију (треба давати предност заједничким, паралелним терминима, или бар онима који су у већини). Утицај речника стручних термина настави намењених појавио се у југословенским језицима касније - тек седамдесетих година; очито то потврђује Шулеков хрватски речник (Хрватско-юемачко-талијански рјечник знанственог називља, 1874 и 1875), а и словеначки Цигалеов речник (Знанствена терминологија с посебним обзиром на средна училишча, 1880). Б. Хавранек је у вези с тим детаљно анализирао семантичке и функционалне области лексичких елемената који су преузимани у хрватски и словеначки књижевни језик у другој половини 19. века и показао да су биле преузимане речи према комуникативним потребама језика примаоца. При том радило се о називима општих појмова из културе, као словеначко pojem, nazor, smer, učinek, dovtip, vpliv, о речима административно-правним терминима (listina, urad, uradnik, ustava), о природнонаучним (gmota, krožnica, obzor, sadra, ustroj), о називима ствари из савремене цивилизације, нпр. pogon, vlak, železnice, tisk, tiskarna, teplomer и сл. Слично је било и при преузимању у хрватски језик. Заслугом Шулековом прихваћене су у хрватском језику многе речи из хемијске терминологије које је у чешком језику створио Ј. С. Пресл, нпр. киселина, угљик, кисик, водик, плин. Посебно место заузимају преузети фискултурни термини 
чије преузимање је потпомогнуто Тиршовом соколском гимнастичком терминологијом (преузимали су је делимично и други словенски језици). - Хавранеково излагање о овој проблематици има синтетички карактер, у погледу материјала ослања се и на словеначке и на хрватске радове, његов новум је у интерпретацији при чему се полази од сазнања тада обрађене теорије књижевног језика.

3. У следећем периоду - од педесетих година - интересовање Б. Хавранека за проблематику југословенских језика кретало се у другом правцу. При том користио је конкретна лична и стечена сазнања из стручне литературе за извођење општих закључака који се, пре свега, односе на развој словенских књижевних језика. Б. Хавранек, као што је познато, спада у осниваче теорије књижевног језика и у челне представнике нових посебних дисциплина - историје књижевног језика и упоредног и конфронтационог проучавања словенских књижевних језика. Што је проблематика развоја, историје књижевних језика, која је, према савременом научном контексту, на првом месту привлачила Хавранеково истраживачко интересовање, у складу је с постепеним развитком дисциплина које као предмет изучавања имају поједине словенске језике или њихово конфронтационо проучавање. Приликом конфронтационих проучавања добро му је послужио његов пионирски рад из тридесетих година, синтетичка монографија Vývoj spisovného jazýka českého (Развитак чешког књижевног језика - Praha 1936), која, у методолошки јасно одређеној форми, даје карактеристику развоја чешког књижевног језика до савременог доба, истичући његов функционални и социјални аспект.

Б. Хавранек се после Другог светског рата интензивно бавио и проблематиком развитка књижевног језика с упоредног славистичког становишта, подвлачећи уопштене закључке, и то у периоду интензивних припрема за обнову међународних конгреса слависта и за обезбеђење организовања међународне славистичке сарадње. Резултате општег третмана ове проблематике поднео је и на међународној конференцији одржаној у Београду 1955. г. (резиме је објављен у зб. Београдски међународни славистички састанак 1955, Београд 1957, с. 545), у пуном, прерађеном облику објављени су затим у зб. Československé př̀ednášky pro IV. mezinárodní sjezd slavistü v Moskvě (Praha 1958, с. 47). Београдски реферат био је, у основи, унесен у зб. Studie o spisovném јаzyce, 1963, под називом K obecným vývojovým zákonitostem spisovných jazykü (О општим законитостима развоја књижевних језика, с. 90). У вези с тим вредно је помена да је већ на II међународном конгресу слависта у Варшави, 1934. г. Б. Хавранек поднео реферат о проблематици упоредног проучавања словенских књижевних језика, у коме је покушао теоријски да образложи 
ову проблематику. Што тај реферат уопште није објављен, Б. Хавранек објашњава тиме што тада још нису постојали погодни услови за такву врсту проучавања. У информацији о II конгресу, објављеној у часопису Slovo a slovesnost 1,1935, с. 68, изразио је жаљење што је на конгресу слабо било заступљено толико неопходно проучавање књижевних језика. Да је Б. Хавранек био присутан на овогодишњем састанку слависта, посвећеном специјално проблематици развоја једне групе словенских књижевних језика, сигурно би био задовољан тиме колико се за 40 година, широко и дубоко, развило проучавање књижевних језика у славистичким центрима.

У својим ка уопштавању усмереним радовима из овог периода Б. Хавранек је концентрисао пажњу, с једне стране, на опште законитости развоја словенских књижевних језика и то с посебним акцентом на однос према развоју дате етничке заједнице, тј. према социјалним факторима - а додајмо - и специјално комуникативним, с друге пак стране осврће се на разнолике, специфичне изразе тих општих тенденција у појединим књижевним језицима. Међутим, приликом праћења специфичности, специфичних црта, често је подсећао на неке чињенице које се тичу развоја и карактера југословенских књижевних језика. (Навешћемо их укратко у закључку.)

4. У периоду шездесетих година Б. Хавранек је учествовао на састанку, организованом 1964. г. у Београду, посвећеном сећању на кодификатора новог српскохрватског књижевног језика - Вука Стефановића Караџића, а поводом стогодишњице његове смрти. Ова конференција је на широком плану подстакла интересовање за проблематику књижевног језика у југословенским лингвистичким центрима и у рефератима страних слависта, специјалиста за проучавање књижевног језика (Б. Хавранек, В. В. Виноградов, Н. И. Толстој, Р. Оти и др.), а допринела је проширењу и продубљивању методолошке основе ових проучавања. И у реферату Б. Хавранека, који је поднео на овој конференцији - објављен је у зб. Анали Филолошког факултета (Вуков зборник II, Београд 1965, с. 259), под називом Значај Вука Стефановића Карачића за развој српскохрватског къижевног језика, при оцени значаја Вука Караџића, долазе до изражаја неки општи и специјални критеријуми који полазе од постављене теорије књижевног језика. Вукова делатност и Вуков значај за конституисање и за даљи развитак српскохрватског књижевног језика не оцењује се изоловано као индивидуално дело него повезано са савременим идејним условима и потребама дате заједнице. Вуково приклањање народном језику објашњава се идејним коренима савременог романтизма с указивањем на паралелну ситуацију у другим словенским књижевним 
језицима који су настајали или стварани у првој половини 19. в. Што се тиче конкретне основе књижевне норме, првобитно њено исходиште био је његов властити херцеговачки дијалекат. Међутим, Вук је на основу правилног познавања и интуитивног осећања општенародне улоге и специфичног задатка књижевног језика, које развијени књижевни језик мора да врши, постепено ту основу модификовао и тако превазишао опасност од уског схватања локалног типа језика, а омогућио је и везу са старијом литерарном традицијом (с традицијом језика дубровачке књижевности). У понешто прерађеној и модификованој форми Б. Хавранек се вратио идејама изреченим на београдском састанку у чланку Význam Vuka Stefanoviće Karadžiće pro vývoj spisovného jazyka srbocharvátského - y зб. Slavica Pragensia VI, посвећеном стогодишњици смрти Вука Стефановића Караџића (Praha 1964).

У периоду шездесетих година имао је Б. Хавранек и неколико боравака с предавањима на југословенским универзитетима. Предавао је о функционалној и структуралној лингвистици прашке школе (Принципи прашке лингвистичке школе, Зборник за филологију и лингвистику, књ. XIII/1, Нови Сад 1970, с. 7), о теорији књижевног језика (Теорија књижевног језика, Jezik in slovstvo 14, 1969, с. 196) и о проблематици мешања језика (Проблематика мијешаға језика, Задарска ревија 13, 1964, с. 177). Приликом једног од последњих боравака у Југославији - на другом састанку међународне комисије за словенске књижевне језике, одржаном 1973. г. у Скопљу, знатно је допринео, подстицајним општим напоменама у дискусији, разјашњавању актуелне проблематике, тј. односу говорних форми према свом књижевном језику (в. резиме дискусија у зб. Говорните форми и словенските литературни јазици, Скопје 1973, с. $84,134,166)$.

Пружили смо глобалну, али не и потпуну карактеристику радова Б. Хавранека, у којима се бавио општом проблематиком или појединачним проблемима словенских књижевних језика на тлу Југославије и покушали да укажемо и на разлике у главном интересовању у појединим периодима његова научног развоја. Истицали смо при том теоријско-методолошки приступ и допринос расветљавању факата са гледишта израђених принципа теорије књижевног језика и упоредног проучавања словенских књижевних језика. Сада ћемо покушати да ове принципе глобално окарактеришемо уз допуну илустративних факата које је Б. Хавранек наводио.

У развоју те орије књ ижевног је зика, формулисаној у оквиру прашке школе, од самог почетка је истицан функционални аспект у различитој мери и разнолико повезиван са шире социјалним аспек- 
том. За решење конкретних проблема књижевног језика и његове норме - у савременом синхроном стању и у развоју - важно је било истаћи функционалну специфичност књижевног језика у односу на друге облике народног језика. Ова функционална специфичност проистиче из специјалних комуникативних потреба које књижевни језик мора да задовољи; ове потребе пак изискују стварање нових средстава или прилагођавање, адаптацију, већ постојећих. На почетку, тридесетих година, у оквиру прашке теорије књижевног језика, говорило се непосредно о аутономном карактеру књижевног језика у односу на некњижевне облике. У одлучујуће црте књижевног језика у односу на те некњижевне облике спада и његова полифункционалност; стога је за упознавање развоја књижевног језика и за његову типолошку карактеристику важно пратити развој његових функционалних стилова.

Рекли смо већ да је Б. Хавранек учинио много за развитак теорије књижевног језика и за конституисање нове дисциплине - упоредно $u$ конфронтационо проучавағе словенских книжевних језика. Непроцењива су његова оштроумна запажања и подстицаји који су произилазили из општих методолошких ставова, али при том нису заобилазили конкретизацију и илустрацију које су сведочиле о дубокој славистичкој ерудицији и често су грађене на чињеницама из југословенских књижевних језика. За највредније треба сматрати оне импулсе и запажања који су допринели и доприносе конституисању типологије словенских књижевних језика. Типологија књижевних језика, на којој су засновани радови совјетских, југословенских и чешких лингвиста (Н. И. Толстоја, Д. Брозовића, М. М. Гухманова, Б. Хавранека, А. Једличке и В. Барнета), структурно се, за разлику од класичне типологије, граде на функционалним карактеристикама. Управо у радовима Б. Хавранека налазимо истакнуте многе одлучујуће и специфичне црте које карактеришу књижевне језике; у ауторовим новијим поменутим радовима из области типологије књижевног језика ове црте су систематизоване. Реч је о таквим цртама (које је још Б. Хавранек истакао), као што је дужина развитка књижевног језика, књижевне традиције и његов непрекинути развитак с једне стране, или прекидани и неравномерни развој - с друге стране. Важна двојност опозиционих црта је и развитак књижевног језика из једног центра (наравно уз утврђивање учешћа и других области), као што је то, нпр. у чешком књижевном језику, или, насупрот томе, постојање неколико развојних центара, како је то, према Хавранеку, нпр. у српскохрватском књижевном језику. Типске црте карактеристичне за словенске књижевне језике Б. Хавранек, по правилу, види у опозиционим односима. Тако је то, нпр. када се тиче и односа књижевног језика 
(писаног) према говорном. У новом српском књижевном језику (Вуковом) доминантна је управо усмереност ка говорном типу језика за разлику, нпр. од првобитне усмерености новог чешког књижевног језика на писану форму, надовезујући се на традицију из периода хуманизама. С тим је повезана и следећа црта - коју је такође још Хавранек истакао - питање структурне разлике између књижевног и свакидашњег говорног језика; знатна разлика је карактеристична за чешки књижевни језик, насупрот томе српски, као и словеначки књижевни језик, карактерише мала разлика.

Већ у својим првим радовима Хавранек као две важне типске црте, које су и временом условљене, наводи прихватање или одбацивање страних елемената и утицаја, дакле, толерисање страних елемената, а насупрот томе пуристички отпор према њима; ову опозицију илуструје, нпр. различитим приступањем овим елементима у развоју српске и хрватске језичке културе и подсећа на развојне промене у том погледу карактеристичне за ситуацију у чешком. Конкретна пуристичка усмереност или толерантност условљени, свакако, временом, зависе од идејних основа и повезани су и са историјским условима развитка датог књижевног језика. Уопштено може се говорити о сусрету двеју супротних тенденција националне и интернационалне. Конкретни изрази тих тенденција могу, дакако, у појединим језицима да буду различити.

Проучавање историје књижевних језика нужно прелази у праћење развојног кретања у језику. У позитивне вредности прашке школе неоспорно спада то што је с опште теоријског гледишта обрадила однос синхроније и дијахроније и што је дијахроно схватање развојног кретања и динамике развоја допунила појмом синхроне динамике. Синхрона динамика се огледа у односу између традиционалних и иновацијских елемената који у књижевном језику и његовој норми постоје у датом добу. И док су традиционални елементи и појаве потпомагани одређеним цртама књижевног језика, као што су, нпр. писана форма, културна и литерарна традиција, кодификована норма књижевног језика и језичко образовање у оквиру ње, продор и синхроно постојање иновацијских елемената повезани су са функционисањем књижевног језика у конкретним социјалним условима и то са захтевом да се задовоље непрестано променљиве комуникативне потребе. Проблематика односа између традиционалних и иновацијских елемената у књижевној норми, иницирана тридесетих година посебно од стране Б. Хавранека и решавана тада у полемичком духу у корист иновацијских елемената, остаје непрестано у центру интересовања теорије књижевног језика у разним земљама и прорађује се са све ширих гледишта. У односу тих елемената могуће је 
видети сусрет двају супротних тенденција, тенденције ка очувању датог стања књижевног језика и иновационе тенденције која произилази из природне промене језика као социјалне појаве.

У значајне и карактеристичне црте у развоју појединих словенских књижевних језика спада и улога великих личности културног и научног живота у стварању, мењању и устаљивању књижевног језика (у његовој стандардизацији). Ове личности су на посебан начин узимале учешће у развоју језика, пре свега, у периоду народног препорода који се временски у развоју појединих словенских књижевних језика не поклапа потпуно. Отуда је и Б. Хавранек поредио нпр. Вукову делатност и ставове с делатношћу и концепцијама Ј. Добровског, кодификатора чешког књижевног језика из доба препорода у области граматичког система.

Развитак изучавања књижевног језика с опште теоријског гледишта и конкретног проучавања појединих књижевних језика, њиховог развоја и савременог стања данас је необично жив. Развија се и методологија а обрађује се и систем појмова и терминолошки апарат. На тај развитак данас делују и неке граничне дисциплине - у последње време нарочито социолингвистика. Као плодан и водећи показује се појам језичка ситуација с којом се оперише како у социолингвистичким радовима тако и у радовима из теорије књижевног језика. То је комплексан појам који обухвата језички, социјални и комуникативни елеменат. Проблеми које у области проучавања књижевног језика треба решавати или где тражити нова решења су бројни. Језичка ситуација књижевног језика народа Југославије је, како у дијахроном тако и у садашњем стању виђеном синхроно, многострука и сложена. Њеном решењу ће сигурно допринети и аспект примене принципа варијабилности и синхроне динамике с којима у својим радовима о словенским књижевним језицима оперише Б. Хавранек. На крају додајмо да конфронтационо проучавање и конфронтациони аспекти доносе продубљавање нашег познавања у оба правца и то и за упознавање конфронтованог језика и домаћег или полазног. Потврђује се, наравно, како је то често и Б. Хавранек констатовао, да резултате који се односе на један језик (и његов развој) није могуће генерализовати, ни механички преносити на друге језике. Сваки књижевни језик је специфичан, специфичне су законитости његова развитка, специфично је његово савремено стање. 